\title{
䪽素胞の病態に関する臨床生化学的研究
}

\author{
北進一・鈴木 貢・小寺正克:三上弘之・盛 女子・伝法谷千寿子
}

\section{Clinico-biochemical studies on pathosis of jaw cysts}

\author{
Shin-ichi Kita - Mitsugu SuzukI - Masakatsu Kodera - Hiroyuki Mikam \\ Fumiko MorI - Chizuko DenpoyA
}

\section{I. 粕}

頻售胞の発育機序に関しては，現在まで数多くの報告 が見受けられる1 10). しかし䆣胞内容液の停滞機满につ いては，いまだ全てが明らかにされていない。

従来，烡胞内容液の由来については，漫透圧や半透膜

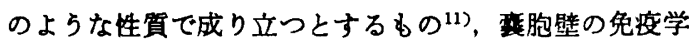

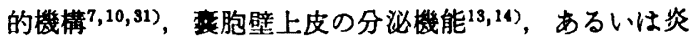
症細胞の液化機枟による1,18 20) とするものなどが報告さ れている。

われわれは，各種䫅表胞の内容液の生化学的分析と， 衰胞壁の組織化学的酵素活性の検討を併せ行い，その結 果, 内容液成分の由来に関して襄胞壁には，一般の細胞 壁にみられるよらな能動輸送的機序の関与を示唆する所 見がみられた。

\section{II. 研 究 方 法}

\section{1. 凟料}

研究対象の顯衰胞は, 弘前大学医学部附属病院歯科口 腔外科で取り报ったものから選択した歯根妻胞，術後性

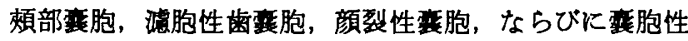
エナメル上皮腫について，これら辜胞の内容液と同一症 例の血液を採取して資料とした。

\section{2. 万法}

1）血清と震胞内容液の生化学的性状は，採取した血 液および重胞内容液を遠心沈殷し，その上清を通常の臨 床生化学的検查に供した。测定値は平均値とその標準誤 差で示した。

2）血清と衰胞内容液の成分々析は，採取した血液お よび衰胞内容液を遠心沈股し，その上清を凍結乾燥した のち, 一定量を $\mathrm{K} \mathrm{Br}$ と混合して disc を作り，Japan

弘前大学医学部齿科口腔外科（主任：鉿木貢教授） Clinic of Dentistry and Oral Surgery, Hirosaki University School of Medicine (Chief: Prof. Mitsugu Suzuki)

受付：昭和51年11月 8 日
Spectroscopic Co. Ltd., DS 601 F および RIA-2 type の I-R Spectra Photometer で吸収を測定した，脂質は Folch 抽出法 ${ }^{22}$ で得たものを $\mathrm{K} \mathrm{Br}$ サント゚イッチ法に より赤外線の吸収を測定した。

3）港胞壁の組織化学的検査の方法は，手術時に摘出 した咅胞を直ちに $-20^{\circ} \mathrm{C}$ の冷揀庫に保存し，倲結した のち $-20^{\circ} \mathrm{C}$ 飞調節されたクリオスタット (Lipshaw Cryotome, Model 1900 type U.S.A.) 中て 8 10 $\mu$ の 連繶切片 (cross section) を作製した。

コハク酸脱水素醉素活性（以下 SDH 活性之略）の証 明法は Nachlas et al. ${ }^{28)}$ の方法行従い，かつ、できる たけ早期に行らよらにした。なお，脱水素醭素活性娭出 のための水素受容体には Nitro-BT を用いた。

乳酸脱水絜酵慗活性（以下 LDH 活性之略）と glucose-6-phosphate dehydrogenase 活性の証明は BarkaAnderson ${ }^{24)}$ の方法, $\mathrm{Na}^{+}-\mathrm{K}^{+}$-ATPase 活性は WachsteinMeisel25) の方法により，それぞれ検出した。

\section{III. 結果}

\section{1. 電解質イオン}

一般の細胞における場合の電解質イオンは, 細胞膜を 介して細胞の内外で一定の割合を保っている．金子 ${ }^{27} に$

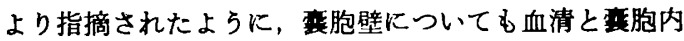
溶液の電解質イオンの割合を知ることにより，壁の透過 性あるいは壁を介しての物質輸送機構の有無について知 る手掛りになり得ると考えられる。

表 1 は各種变胞内溶液の電解質イオンについて，臨床 的に炎症症状を伴わないむのと伴うむのに分けてみたも のである。 $\mathrm{Na}, \mathrm{K}, \mathrm{Cl}$ イオンの各含有量は，それぞれ 血清値とほほ流似するか，特徽的なことは臨床的に感染 状態に扐かれた謈胞の場合，内容液中のKイオンが有意 の差をもって上昇を示す成績を得たことである.

なお，吉田 ${ }^{21}$ に上れば，丵胞内容液中には $\mathrm{Cl}$ イオン の著しい增量が見られると報告しているが，われわれの 成績からは炎症症状を伴う場合に括いても，整胞内容液 中の $\mathrm{Cl}$ イオン值に增加の傾向は示されなかった。

つぎに，電解質イオンが体液より咅胞内に移行する可 


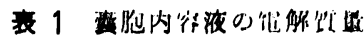

\begin{tabular}{|c|c|c|c|c|c|c|}
\hline Components & Serm & Radicular Cyst & $\begin{array}{l}\text { Postoperative } \\
\text { Buccal Cyst }\end{array}$ & $\begin{array}{l}\text { Follicular } \\
\text { Dental (ys) }\end{array}$ & l'issural ('yst & $\begin{array}{l}\text { Adamantinoma } \\
\text { Cysticum }\end{array}$ \\
\hline $\mathrm{Na}(\mathrm{mEq} / \mathrm{L})$ & $\begin{array}{l}139.9 \\
\pm 1.2\end{array}$ & $\begin{array}{l}\text { (9) } 136.7 \pm 1.9 \\
\text { (4) } 119.2 \pm 11.1\end{array}$ & $\begin{array}{l}\text { (10) } 134.2 \pm 3.6 \\
\text { ( 5) } 132.2 \pm 1.9\end{array}$ & $\begin{array}{l}\text { (4) } 136.0 \pm 1.2 \\
\text { (4) } 113.2 \pm 9.1\end{array}$ & $\begin{array}{l}\text { (2) } 138.0+2.1 \\
\text { (1) } 131.0\end{array}$ & (2) $138,0 \pm 2.0$ \\
\hline $\mathrm{K}(\mathrm{mEq} / \mathrm{L})$ & $\begin{array}{r}4.2 \\
\pm 0.1\end{array}$ & $\begin{array}{l}\text { (9) } 4.2 \pm 0.2 \\
\text { (4) } 13.4 \pm 3.4\end{array}$ & $\begin{array}{ll}\text { (10) } & 4.7 \pm 0.1 \\
\text { (5) } & 8.5 \pm 2.2\end{array}$ & $\begin{array}{l}\text { (4) } 3.8 \pm 0.2 \\
\text { (4) } 17.3 \pm 3.0\end{array}$ & $\begin{array}{l}\text { (2) } 4.3 \pm 0.2 \\
\text { (1) } 11.5\end{array}$ & 4. $1 \pm 0.5$ \\
\hline Cl $(\mathrm{mEq} / \mathrm{L})$ & $\begin{array}{r}103.2 \\
\pm 0.7\end{array}$ & $\begin{array}{l}\text { (9) } 104.8 \pm 1.6 \\
\text { (4) } 100.8 \pm 1.9\end{array}$ & $\begin{array}{l}\text { (10) } 107.4 \pm 1.6 \\
\text { ( 5) } 99.2 \pm 3.8\end{array}$ & $\begin{array}{l}\text { (4) } 105.3 \pm 1.9 \\
\text { (4) } 88.7 \pm 1.5\end{array}$ & $\begin{array}{l}\text { (1) } 107.0 \\
\text { (1) } 98.0\end{array}$ & (2) $105.0 \pm 1.4$ \\
\hline
\end{tabular}

* : Infected Case, $\pm:$ Standard Error, ( ): Number of Case's

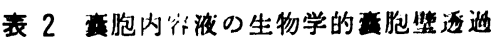

\begin{tabular}{|c|c|c|c|c|c|c|c|c|c|c|c|c|c|}
\hline \multirow{2}{*}{\multicolumn{2}{|c|}{ Ringer }} & \multicolumn{4}{|c|}{ Apical Cyst } & \multicolumn{4}{|c|}{ Postoperative Cyst } & \multicolumn{4}{|c|}{ Cystic Ameloblastoma } \\
\hline & & Fluid & $30 \mathrm{~min}$ & $90 \mathrm{~min}$ & $24 \mathrm{~h}$ & Fluid & $30 \mathrm{~min}$ & $90 \mathrm{~min}$ & $24 \mathrm{~h}$ & Fluid & $30 \mathrm{~min}$ & $90 \mathrm{~min}$ & $24 \mathrm{~h}$ \\
\hline & Exchange & \multicolumn{4}{|c|}{$\underset{4 \mathrm{~m} l}{\mathrm{R}} \longrightarrow \underset{4 \mathrm{ml}}{\mathrm{F}}$} & \multicolumn{4}{|c|}{$\underset{5 \mathrm{ml}}{\mathrm{R}} \longrightarrow \underset{5 \mathrm{ml}}{\mathrm{F}}$} & \multicolumn{4}{|c|}{$\underset{20 \mathrm{~m} l}{\mathrm{R}} \longrightarrow \underset{20 \mathrm{ml}}{\mathrm{F}}$} \\
\hline $\mathrm{Na}$ & $152 \mathrm{mEq} / \mathrm{l}$ & 139 & 145 & 144 & 139 & 145 & 136 & 134 & 142 & 141 & 141 & 140 & 143 \\
\hline $\mathbf{K}$ & 3.9 & 4. 1 & 3.5 & 4.3 & 5.7 & 4. 0 & 4.5 & 5.0 & 3. 9 & 3.6 & 4.6 & 4.4 & 3. 6 \\
\hline $\mathrm{Cl}$ & 157 & 108 & 119 & 110 & 108 & 118 & 116 & 112 & 113 & 105 & 111 & 106 & 103 \\
\hline $\mathbf{P}$ & $1.5 \mathrm{mg} / \mathrm{d} l$ & 3. 1 & 2.4 & 3. 7 & 4.1 & 0.5 & 0.6 & 1.3 & 0.5 & 2. 9 & 3. 0 & 3.5 & 2.5 \\
\hline $\mathrm{Ca}$ & 10. 2 & 8. 2 & 8.4 & 8.4 & 7. 3 & 6.8 & 7. 3 & 7.9 & 5.5 & 7. 0 & 7.4 & 7.5 & 5.7 \\
\hline
\end{tabular}

F: Fluid, R: Ringer

表 3 集胞内容液の酜絭

\begin{tabular}{|c|c|c|c|c|c|c|c|c|c|c|c|}
\hline \multicolumn{2}{|c|}{ Components Serm } & \multicolumn{3}{|c|}{ Radicular Cyst } & \multicolumn{3}{|c|}{$\begin{array}{l}\text { Postoperative } \\
\text { Buccal Cyst }\end{array}$} & \multicolumn{2}{|c|}{$\begin{array}{l}\text { Follicular } \\
\text { Dental Cyst }\end{array}$} & \multicolumn{2}{|c|}{ Fissural Cyst } \\
\hline $\begin{array}{l}\text { Alkaline- } \\
\text { Phosphatase } \\
\text { * }\end{array}$ & $\begin{array}{l}\text { K.A.U. } \\
\text { 8. } 1 \pm 1.1\end{array}$ & $\begin{array}{l}(10) \\
(3)\end{array}$ & $\begin{array}{r}9.2 \pm \\
46.1 \pm\end{array}$ & $\begin{array}{r}1.2 \\
14.7\end{array}$ & $\begin{array}{l}(10) \\
(7)\end{array}$ & $\begin{array}{l}11.0 \pm \\
20.1 \pm\end{array}$ & $\begin{array}{l}2.6 \\
4.6\end{array}$ & $\begin{array}{l}\text { (4) } \\
\text { (3) }\end{array}$ & $\begin{array}{r}8.8 \pm 2.2 \\
15.2 \pm 4.9\end{array}$ & $\begin{array}{l}\text { (2) } \\
\text { (1) }\end{array}$ & $\begin{array}{l}21.0 \pm 1.7 \\
5.7\end{array}$ \\
\hline $\begin{array}{l}\text { Acid- } \\
\text { Phosphatase } \\
*\end{array}$ & $\begin{array}{l}\text { K.A.U. } \\
3.5 \pm 0.5\end{array}$ & $\begin{array}{l}(10) \\
(3)\end{array}$ & $\begin{array}{r}9.4 \pm \\
25.2 \pm\end{array}$ & $\begin{array}{l}1.8 \\
5.5\end{array}$ & $\begin{array}{l}(11) \\
(8)\end{array}$ & $\begin{array}{l}24.7 \pm \\
15.5 \pm\end{array}$ & $\begin{array}{l}\text { 4. } 1 \\
2.7\end{array}$ & $\begin{array}{l}\text { (3) } \\
\text { (3) }\end{array}$ & $\begin{array}{l}20.0 \pm 6.0 \\
16.2 \pm 3.8\end{array}$ & $\begin{array}{l}\text { (2) } \\
\text { (1) }\end{array}$ & $\begin{array}{l}22.0 \pm 2.3 \\
6.7\end{array}$ \\
\hline $\begin{array}{l}\text { L.D.H. } \\
\text { * }\end{array}$ & $\begin{array}{r}\text { units } \\
307.3 \pm 44.1\end{array}$ & $\begin{array}{l}(10) \\
(4)\end{array}$ & $\begin{array}{l}1423.0 \pm \\
1372.5 \pm\end{array}$ & $\begin{array}{l}163.8 \\
368.4\end{array}$ & $\begin{array}{l}(11) \\
(8)\end{array}$ & $\begin{array}{l}1898.6 \pm \\
1688.0 \pm\end{array}$ & $\begin{array}{r}45.2 \\
174.6\end{array}$ & $\begin{array}{l}(2) \\
(3)\end{array}$ & $\begin{array}{l}1833.5 \pm 82.7 \\
1693.3 \pm 8.8\end{array}$ & $\begin{array}{l}\text { (1) } \\
\text { (1) }\end{array}$ & $\begin{array}{l}386.0 \\
170.0\end{array}$ \\
\hline
\end{tabular}

*: Infected Case, \pm : Standard Error, ( ): Number of Cases

能性について検討するため, 血液と等張な Ringer 水を 唯胞内容液と置き換えたのち，再び内容液中の電解質イ オンについて調へててみた．その結果は表 2 に示すよ5 に, 一般の頡骨内露胞では元の値に戻るのに 90 分以上を 要するが，エナメル上皮腫の場合は30分以内に元の値に 戻ることを示す成績が得られた。

\section{2. 酻}

表了に示すように，県胞内容夜中の alkaline phosphatase 活性は同一患者の血清值とほほ類似している が，交胞が感染するとその值は上昇する。，一方， acid phosphatase 活性は、エナメル上皮腫の場合を除きいず れの要胞においても著しい上昇を示した. さらにL.D.H. 


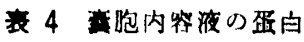

\begin{tabular}{|c|c|c|c|c|c|c|}
\hline \multicolumn{2}{|c|}{ Components Serm } & Radicullar C'yst & $\begin{array}{l}\text { Postoperative } \\
\text { Buccal Cyst }\end{array}$ & $\begin{array}{l}\text { Follicular } \\
\text { Dental Cyst }\end{array}$ & Fissural Cyst & $\begin{array}{l}\text { Adamantinoma } \\
\text { ('ysticum }\end{array}$ \\
\hline $\begin{array}{l}\text { Total Protein } \\
\text { * }\end{array}$ & $\begin{array}{l}\mathrm{mg} / \mathrm{d} l \\
7.1 \pm 0.3\end{array}$ & $\begin{array}{l}\text { (8) } 7.9 \pm 0.7 \\
\text { (4) } 7.1 \pm 0.5\end{array}$ & $\begin{array}{l}\text { (13) } 7.0 \pm 0.6 \\
\text { ( } 6) 7.2 \pm 0.3\end{array}$ & $\begin{array}{l}\text { (5) } 7.4 \pm 1.2 \\
\text { (4) } 4.7 \pm 0.7\end{array}$ & $\begin{array}{l}\text { (2) } 8.9 \pm 0.5 \\
\text { (1) } 7.2\end{array}$ & (2) $4.6 \pm 0.3$ \\
\hline $\begin{array}{l}\text { Albumin } \\
*\end{array}$ & $4.8 \pm 0.2$ & $\begin{array}{l}\text { (6) } 3.3 \pm 0.5 \\
\text { (4) } 3.1 \pm 0.4\end{array}$ & $\begin{array}{l}\text { ( } 8) 4.0 \pm 0.4 \\
\text { ( } 7) 4.3 \pm 0.4\end{array}$ & (3) $3.4 \pm 0.5$ & $\begin{array}{l}\text { (1) } 4.5 \\
\text { (1) } 3.7\end{array}$ & (2) $2.9 \pm 0.3$ \\
\hline $\begin{array}{l}\alpha_{1} \text {-globulin } \\
*\end{array}$ & $0.3 \pm 0.1$ & $\begin{array}{l}\text { (2) } 0.5 \pm 0.1 \\
\text { (3) } 0.2 \pm 0.02\end{array}$ & $\begin{array}{l}\text { ( } 8) 0.4 \pm 0.1 \\
(7) 0.4 \pm 0.1\end{array}$ & (3) $0.2 \pm 0.1$ & $\begin{array}{l}\text { (1) } 0.2 \\
\text { (1) } 0.4\end{array}$ & (2) $0.2 \pm 0.01$ \\
\hline $\begin{array}{l}\alpha_{2} \text {-globulin } \\
*\end{array}$ & $0.6 \pm 0.1$ & $\begin{array}{l}\text { (2) } 0.5 \pm 0.02 \\
\text { (3) } 0.5 \pm 0.1\end{array}$ & $\begin{array}{l}\text { ( } 8) 0.6 \pm 0.1 \\
\text { ( } 7) 0.8 \pm 0.3\end{array}$ & (3) $0.4 \pm 0.1$ & $\begin{array}{l}\text { (1) } 0.6 \\
\text { (1) } 0.5\end{array}$ & (2) 0.2 \\
\hline$\beta$-globulin & $0.6 \pm 0.1$ & $\begin{array}{l}\text { (6) } 0.6 \pm 0.1 \\
\text { (4) } 0.8 \pm 0.2\end{array}$ & $\begin{array}{l}(8) 0.7 \pm 0.2 \\
(7) 0.7 \pm 0.1\end{array}$ & (3) $1.0 \pm 0.2$ & $\begin{array}{l}\text { (1) } 0.8 \\
\text { (1) } 0.6\end{array}$ & (2) $0.4 \pm 0.1$ \\
\hline$\gamma$-globulin & 1. $2 \pm 0.2$ & $\begin{array}{l}\text { (6) } 3.6 \pm 0.9 \\
\text { (4) } 2.4 \pm 0.5\end{array}$ & $\begin{array}{l}\text { ( } 8) 1.3 \pm 0.1 \\
\text { ( } 7) 1.4 \pm 0.6\end{array}$ & (3) $0.8 \pm 0.1$ & $\begin{array}{l}\text { (1) } 2.1 \\
\text { (1) } 2.1\end{array}$ & (2) $0.9 \pm 0.02$ \\
\hline
\end{tabular}

*: Infected Case, $\pm:$ Standard Error, ( ): Number of Cases

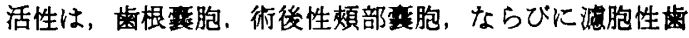
䓋胞において同一患者の血清値よりも著明に高い值を示

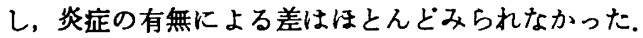

\section{3. 蛋 白 兵}

襄胞内容液中の蛋白成分についてみると, 表 4 のよう に各種の性状の蛋白質を含有して拈り，エナメル上皮腫 内容液の蛋白存在量は分子量の小さいあのが多く, 分子 量の大きくなるに従ってその存在量に减少の傾向がみら れる.しかし他の英胞内容液においては，このような傾 向を示さなかった，この蛋白質成分について，高速液体 クロマトクラフィーによるゲル滤過法を用い，血清との 比較を行ってみた，図1に示すように，albumin が大き い peak を示し， $\alpha$-および $\beta$-globulin がこれに次ぎ， $\gamma$-globulin が最も小さい peak を示した. $\alpha, \beta, \gamma$-globulin の peak の大きさは, 各衰胞の内容液により多少 のばらつきがみられた。

この結果から，䋿胞内容液中の alubumin 含量は，血 清の含量とほ洼等しいか; $\alpha-, \beta-, \gamma$-globulin の含有量 は，それぞれ血清値よりる多いことがわかる。

\section{4. 脂䝯}

衰胞内容液の脂質について調べた鈴木の成績 ${ }^{39}$ によれ ば, Cholesterol 值は血清值にほぼ近似しているが，臨 床的に炎症症状を伴ったものでは，それぞれの倠胞と む，一様にその含有量に低下の傾向がみられた。これと は反対に $\beta$-lipoprotein と triglycerid の含有量は, 感 染によってむしろ上昇を示す成績が得られた，また血清 と内容液中の脂質の性状を比較するため, Folch 法 ${ }^{22)}$ 抽出したものについて赤外線吸収スペクトル法でみる と, 表 6 のごとく血清中に検出されるものの全てが㪓胞
内容液中にも認められた。 またその蕾属からは脂酸，燐 脂質， cholesterol ester などである。しかし胞内容液 中には $1280 \mathrm{~cm}^{-1}$ に脂質成分と思われる 血清には無い 吸収が認められ，この帰属はまだ判明されていないさ らに，脂酸について Gas-chromatography によりその 構成をみると ${ }^{39}$ ， cholesterolester, triglyceride ともに血 清に存在する脂酸が検出される。 しかしその構成配分か 異なり, 血清の標準值に比べて要胞内容液中の cholesterolester は, パルミチン酸とオレイン酸が增加し,リ ノール酸が減少している。また， triglyceride ではハル ミチン酸が増加し、オレイン酸とリノール酸が低下して いた.

\section{5. 組糡化学的所見}

摘出した嫨胞壁上皮層における組織化学的酵素活性の 結果を写直 1 〜 4 に示した。

写真 1 は，残留要胞の上皮層にみられる $\mathrm{SDH}$ 活性を 示したものである。すなわち， $\mathrm{SDH}$ 活性は基底細胞層 に強く，表層に行くに従って弱くなっている，写真 2 は，歯根亯胞壁上皮層の glucose-6-phosphate dehydrogenase 活性を示したものである。 SDH 活性の場合とは 逆に，本活性の分布は表層に最も強く，基底細胞層に行 くに従い弱くなっている. 军南了は, 残留萑胞の LDH 活性の所見であるが，活性の分布は $\mathrm{SDH}$ 活性のそれに 類似する。しかし活性の程度は SDH の場合よりも強陽 性に反応している。 また，電解質のとくに $\mathrm{Na}$ の輸送 には $\mathrm{Na}^{+}-\mathrm{K}^{+}$-ATPase 活性の関与することが知られてい

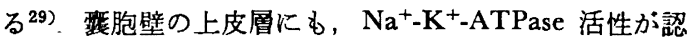
められた（写真 4 ）。 


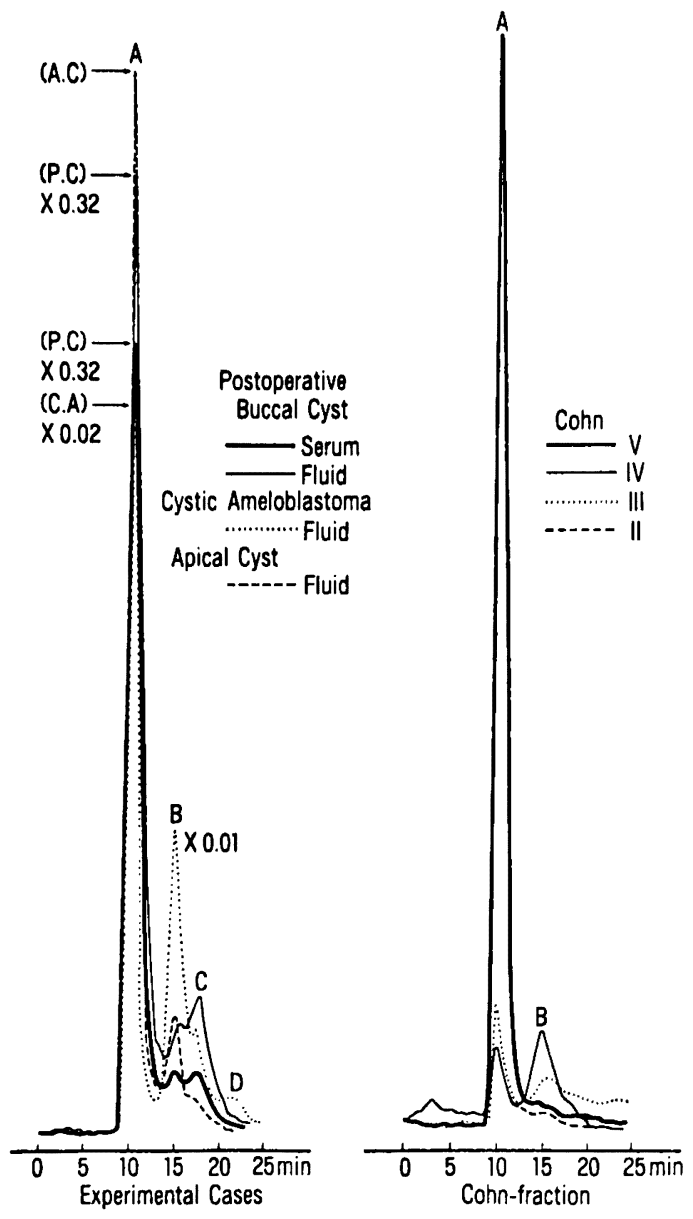

图 1 血消と蓄胞内容液, 標些物質の高速液体り口 マトクラフィー（UVによる检出）

\section{IV. 考察}

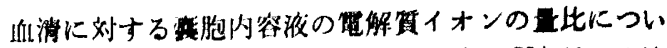

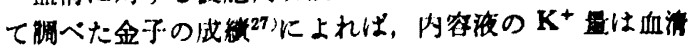
中のそれよりる，やや低い頵向にあるとい5。しかし，

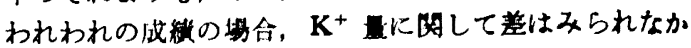

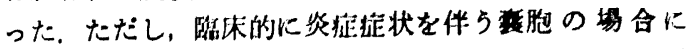
は，その内容波中の $\mathbf{K}^{+}$其が者明に上㚏していることが

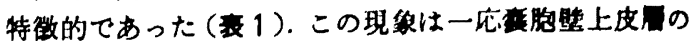

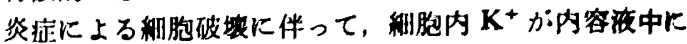
流出した結果であると考えることができる、しかしなが

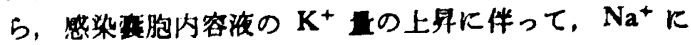
わずかな诚少の倾向をみることができる。

一般的に，細胸内のイオン灌度は一定に保たれている か，これは細胞にはエネルギーを消学して，流れ込んだ

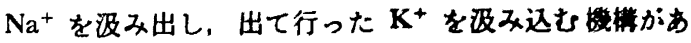
ろからといわれる29)。したがって，われわれの得た成鿓

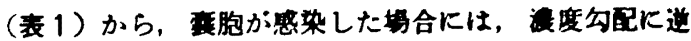
って $\mathrm{Na}^{+}$は体液中に汲み出され， $\mathbf{K}^{+}$を没み込んで、

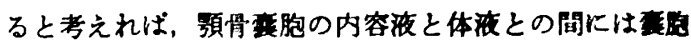

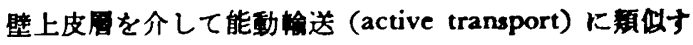
る機楼の存在が示唆される。

なお，われわれの成散では $\mathrm{Cl}^{-}$值には注とんど变物が

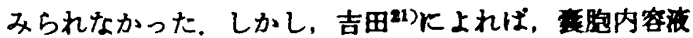
には $\mathrm{Cl}^{-}$が著明に增量しており,これは Donnan の助

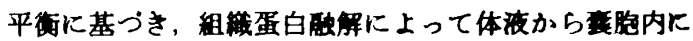
移行するためであるという。

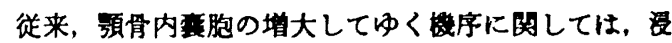

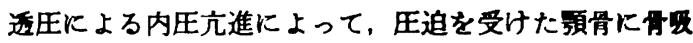
収が生じ，胞が增大して行くと言われる

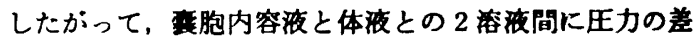

表 5 胞内容液の脂買

\begin{tabular}{|c|c|c|c|c|c|c|c|}
\hline Components & Serm & Radicular Cyst & $\begin{array}{l}\text { Postoperative } \\
\text { Buccal Cyst }\end{array}$ & $\begin{array}{l}\text { Follicular } \\
\text { Dental Cyst }\end{array}$ & Fissural Cyst & \multicolumn{2}{|c|}{$\begin{array}{l}\text { Adamantinoma } \\
\text { Cysticum }\end{array}$} \\
\hline $\begin{array}{l}\text { Cholesterol } \\
\star\end{array}$ & $\begin{array}{r}\mathrm{mg} / \mathrm{d} l \\
180.1 \\
+12.9\end{array}$ & $\begin{array}{l}\text { (9) } 238.0 \pm 34.8 \\
\text { (3) } 168.6 \pm 14.1\end{array}$ & $\left(\begin{array}{l}(13) 180.4 \pm 28.4 \\
(6) 126.6 \pm 36.7\end{array}\right.$ & $\begin{array}{l}\text { (5) } 245.6 \pm 57.8 \\
\text { (3) } 116.6 \pm \quad 7.6\end{array}$ & (2) 97.5 土51.1 & (2) & $105.0 \pm 3.5$ \\
\hline $\begin{array}{l}\text { Phospholipid } \\
\text { * }\end{array}$ & $\begin{array}{c}\mathrm{mg} / \mathrm{d} l \\
191.4 \\
\pm 9.7\end{array}$ & $\begin{array}{l}\text { (4) } 211.2 \pm 22.8 \\
\text { (2) } 117.0 \pm 42.9\end{array}$ & $\begin{array}{l}(8) 121.1 \pm 25.8 \\
(8) 186.1 \pm 55.8\end{array}$ & $\begin{array}{l}\text { (1) } 155.0 \\
\text { (1) } 263.0\end{array}$ & $\begin{array}{l}\text { (1) } 55.0 \\
\text { (1) } 90.0\end{array}$ & (2) & $97.0 \pm 2.1$ \\
\hline Triglycerid & $\begin{array}{c}\mathrm{mg} / \mathrm{d} l \\
123.3 \\
\pm 12.4\end{array}$ & $\begin{array}{l}\text { (4) } 54.0 \pm 12.4 \\
\text { (2) } 108.5 \pm 37.7\end{array}$ & $\begin{array}{l}\text { (6) } 49.8 \pm 8.4 \\
\text { ( } 8) 407.5 \pm 166.3\end{array}$ & $\begin{array}{l}\text { (1) } 40.0 \\
\text { (1) } 101.0\end{array}$ & $\begin{array}{l}\text { (1) } 22.0 \\
\text { (1) } 91.0\end{array}$ & (2) & $46.5 \pm 6.0$ \\
\hline $\begin{array}{l}\text { N.E.F.A. } \\
*\end{array}$ & $\begin{array}{c}\mathrm{mEq} / \mathrm{l} \\
0.5 \\
\pm 0.1\end{array}$ & $\begin{array}{l}\text { (3) } 0.39 \pm 0.2 \\
\text { (2) } 0.1 \pm 0.01\end{array}$ & $\begin{array}{lll}(7) & 0.4 \pm & 0.1 \\
(8) & 0.4 \pm & 0.2\end{array}$ & $\begin{array}{l}\text { (1) } 0.1 \\
\text { (1) } 0.9\end{array}$ & $\begin{array}{l}\text { (1) } 0.1 \\
\text { (1) } 0.2\end{array}$ & (2) & $0.2 \pm 0.2$ \\
\hline $\begin{array}{l}\beta \text {-lipoprotein } \\
*\end{array}$ & $\begin{array}{r}\mathrm{mg} / \mathrm{d} l \\
444.7 \\
\pm 23.0\end{array}$ & & $\begin{array}{l}(7) 270.0 \pm 53.8 \\
(7) 585.7 \pm 254.7\end{array}$ & $\begin{array}{l}\text { (1) } 140.0 \\
\text { (2) } 675.0 \pm 335.9\end{array}$ & $\begin{array}{l}\text { (1) } 350.0 \\
\text { (1) } 450.0\end{array}$ & (2) & $85.0 \pm 3.5$ \\
\hline
\end{tabular}

N.E.F.A.: Nonesterified Fatty Acid, \pm : Standard Error, *: Infected Case, ( ): Number of Cases 


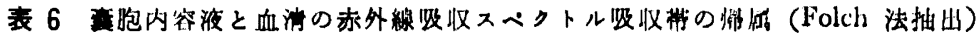

\begin{tabular}{|c|c|c|c|c|c|c|c|}
\hline $\begin{array}{l}\text { Frequency } \\
\left(\mathrm{cm}^{-1}\right)\end{array}$ & Assignment & E్ & $\begin{array}{l}\text { Plasma Lipid* } \\
\text { in Serm }\end{array}$ & $\begin{array}{l}\text { Fluid } \\
\text { (A.C.) }\end{array}$ & $\begin{array}{l}\text { Plasma Lipid } \\
\text { in Fluid (A.C.) }\end{array}$ & $\begin{array}{l}\text { Plasma Lipid } \\
\text { in Fluid (P.C.) }\end{array}$ & $\begin{array}{l}\text { Plasma Lipid } \\
\text { in Fluid (C.A.) }\end{array}$ \\
\hline 3320 & $\gamma-\mathrm{OH}$ & VS & $\mathbf{M}$ & VS & W & W & $\mathbf{W}$ \\
\hline 3080 & $\mathrm{C}=\mathrm{C}-\mathrm{H}$ & $\mathrm{Sh}$ & & $\mathrm{Sh}$ & & & \\
\hline 2940 & $\gamma-\mathrm{CH}$ & W & VS & W & VS & VS & VS \\
\hline 2860 & $\gamma-\mathrm{CH}$ & & S & $\mathrm{Sh}$ & S & $\mathbf{S}$ & $\mathbf{S}$ \\
\hline 1738 & $\gamma \cdot \mathrm{C}=\mathrm{O}$ & & S & & $s$ & $\mathbf{S}$ & $\mathbf{S}$ \\
\hline 1650 & $\mathrm{OH}$ amid $\mathrm{I}$ & VS & & VS & & & \\
\hline 1540 & NH amid II & $\mathbf{S}$ & & S & & & \\
\hline 1440 & $\mathrm{CH}_{3}$ & $\mathbf{M}$ & & $\mathbf{M}$ & & & \\
\hline 1400 & COO- & $\mathbf{M}$ & & & & & \\
\hline 1380 & $\delta \mathrm{CH}_{3}, \mathrm{CH}_{2}$ & & & M & & & \\
\hline 1310 & $\delta \mathrm{NH}$ & W & & & & & \\
\hline 1280 & $?$ & & & & W & W & W \\
\hline 1240 & $P=O$ & $\mathbf{M}$ & & W & & & \\
\hline 1180 & $P=O, \quad P-O-C$ & W & & S & & & \\
\hline 1080 & Cholesteroestel & $\mathbf{M}$ & & $\mathbf{S}$ & & & \\
\hline 725 & $\mathrm{CH}_{2}$ & $\mathbf{M}$ & & $\mathbf{S}$ & W & W & W \\
\hline 600 & $\mathrm{PO}_{4}$ & $\mathbf{S}$ & & $\mathbf{S}$ & & & \\
\hline
\end{tabular}

* Plasma Lipid: Folch Extraction, A.C.: Apical Cyst, P.C.: Postoperative Buccal Cyst, C.A.. Cystic Ameloblastoma, V: Very, S: Strong, W: Weak, M: Medium, Sh: Shoulder

があるとすれば，䥓胞壁を介して Cl- が不均等に分配 されて平衡を保っている状態 (Donnan の平衡) である のかも知れない.

以上に述べたよらに，電解質イオンについて烡胞壁に 物質輸送の機構があるとすれば，その仕事に消費される 呼吸、解糖などの、エネルギー供給の代誎に関する酵素 が壁に存在せねばならない，われわれの成績から，荎胞 壁の上皮層にはS SDH 活性の存在することが示された （写真 1). しかも，この活性の分布は，基底細胞層に反 応か強く，表層に向5に従って活性が減少している。こ のことは本活性の存在するとされている mitochondria が基底細胞層に多く分布することを示すすのであり，こ の mitochondria かi TCA 回路の酸化, 酸化的燐酸化打 よび電子運搬の 3 機能を有し, 細胞呼吸に必要な oxidative enzyme を mitochondria 中に持ち，ATPを生産 して電解質イオン等の榆送のためのエネルギーとして利 用されているすのと考えられる。 また，五炭楉回路の脱 水素醭素である glucose-6-phosphate 脱水素酵素活 性 る，震胞壁上皮層に証明された（写真 2)。この活性の 分布は，TCA 系の SDH 活性の分布とは反対の分布形 式を示し，表層に強く，基底細胞層に向うに従い弱い活 性を示した。本䤃素活性が SDH 活性と反対の関俰にあ ることは，上部消化管の重層扁平上皮に拈いてもみられ ることが報告されている28).すなわち，哓胞上皮層に打 いては，呼吸系と五炭糖回路の両醳素がそれぞれの主た
る局在部位を異にして互いに存在していることを示すす のと考学られる。一方，解糖采酵秦である LDH 活性 は，上皮層の全層にわたって強陽性に認められ（写梖 3)，特に基底細胞層に活性が強く，この点 SDH 活性 と同様の分布形成を示す。この醅素活性の生理学的意義 に関しては不明な点が多いか，一般的に組織再生時に本 活性の著しい上昇をみることより，生体の防御機構の 1 つとして常に毫胞壁の修復機転に関与して活性化してい

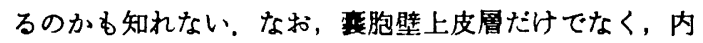
容液中の本活性の高い（表了）ことも，同様の理由によ るむのと考劣られる。

また， $\mathrm{Na}^{+}-\mathrm{K}^{+}$-ATPase は $\mathrm{Na}$ イオンと $\mathrm{K}$ イオンの $2 つ の 一$ 一価陽イオンを必要とする極めて特異なイオン要 求性を示す ATPase であり, 特に $\mathrm{Na}^{+}$の能動梌送に際 して，ATP の分解とイオンの能動輸送との間に密接な 関㐿があると言われている ${ }^{299}$. 套胞壁上皮層において む，写直4のよ5に $\mathrm{Na}^{+}-\mathrm{K}^{+}$-ATPase 反応を諗めるこ とができたか，しかしこの所見が直ちに本活性の存在を 証明するものとは断言しがたく，この活性を特異的に阻 害する ouabain により，活性が㧕制されるか否かにつ き検討することが必要とされる.

以上の組織化学的所見は，爰胞壁上皮層に呼吸ならび に解糖系の酵素が存在することを示するのであり，電解 質イオンの亳胞壁輸送の仕事に消費されるエネルギー源 は，この両系から供給されることが想像される．加え 


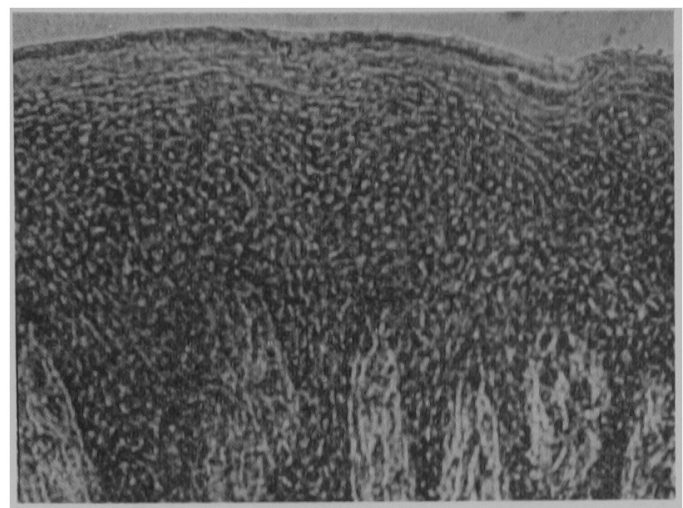

写重 1 Suctinic dehydrogenase $\times 100$

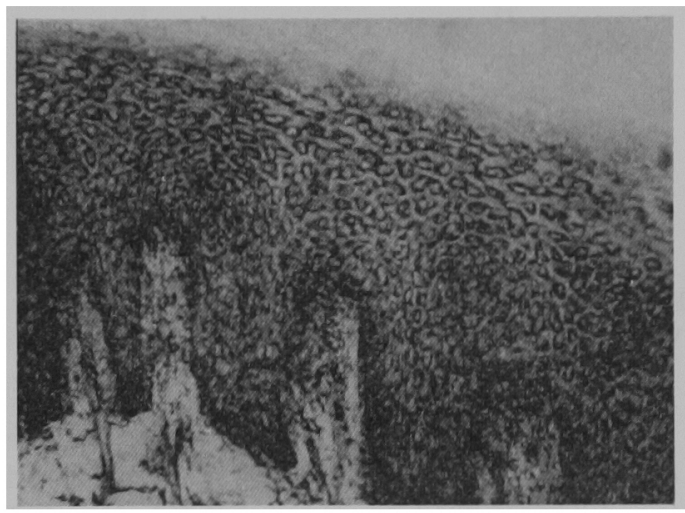

写直 3 Lactic dehydrogenase $\times 100$

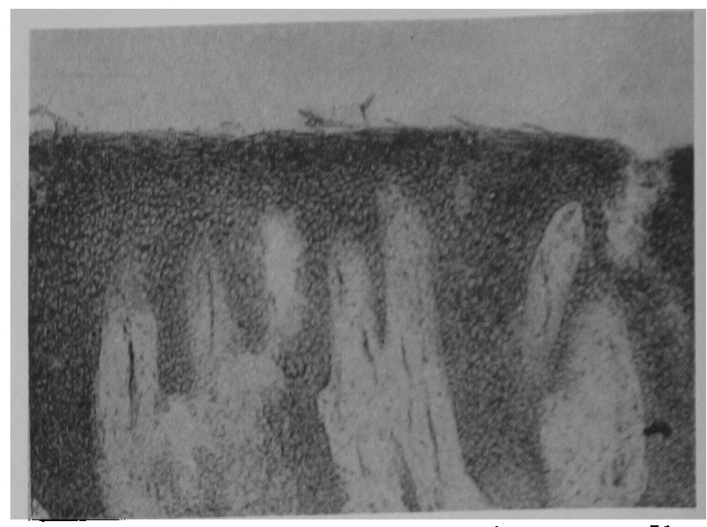

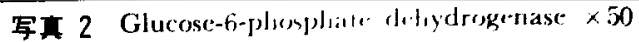

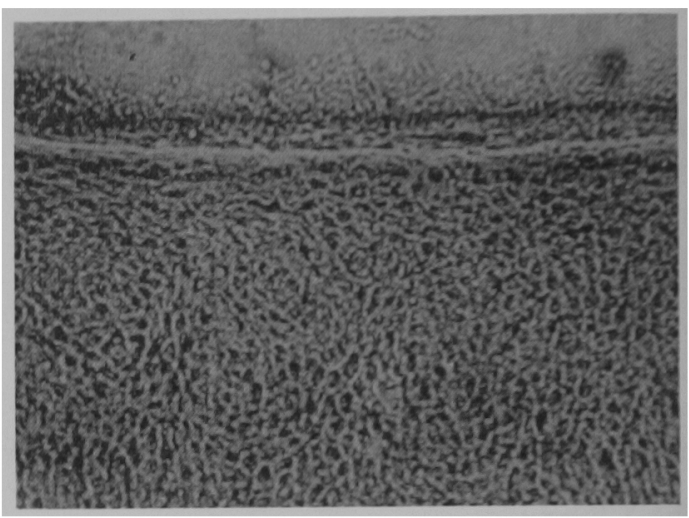

军槙 $\mathrm{Na}^{+}-\mathrm{K}^{+}-$.ATPase $\times 100$

写直 1 コハク酸脱水来酵素活性

写真 2 クルコース6 燐酸脱水慗酝絜活性

写真 3 醉脱水菜醉䋕活性

写直 $4 \mathrm{Na}^{+}-\mathrm{K}^{+}-\mathrm{ATPase}$ 活性

て， $\mathrm{Na}^{+}-\mathrm{K}^{+}$-ATPase の存在がさらに明らかになれば， 趞胞壁には $\mathrm{Na}$ ポンプ機構の存在も示唆されることにな

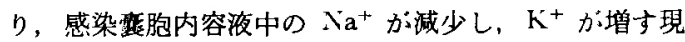
象の説明になり得るものと思われる。

蛋白質成分についてみると，図１に見られるよ5に， エナメル上皮腫では分子量の小さいものが露胞内に多く 見られ，他の顎骨琵胞にはこの㑯向を示さなかった。

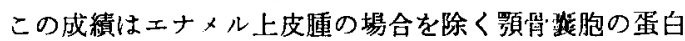
質の乘胞内移行は，単に葆胞壁の分子節 (molecular sieving) ${ }^{38}$ あるいは拆散 (diffusion) ${ }^{38}$ による透過だけと は考えがたく，電解質イオンなどの榆送のための transport chain の役を担っていることが考えられる，たと えば中尾によるど0)，細胞膜に括ける物質の carrier mechanism の1つである transport chain について, $\mathrm{Na}^{+}, \mathrm{K}^{+}$なとの移動体は，たとえば ATP の $\mathrm{P}$ が蛋白 と結合した中間体 P-E があるとして，その P がつぎ
つぎ 1つの部位から他の部位に転移し、それに伴って $\mathrm{Na}^{+}, \mathrm{K}^{+}$の移動がおこるという可能性を示唆してい る.

なお，われわれの成䐜において， $\alpha ， j, \gamma$-globulin 值 が血清値よりも多い点は，従来の報告にみられる Toller

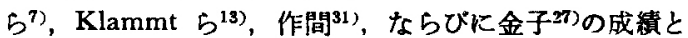

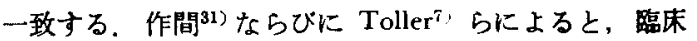

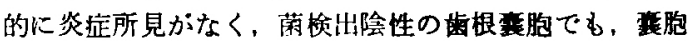
壁には常に炎症像を有し，しかもIgG 産生稩胞と思わ れる形質緗胞が存在することより，胞壁には免疫学的 機序の存在することを示惨し, Toller $5^{7}$ ：相根壁 に同様の機序が関与する可能性を報告している。したが って，蛋白成分の整胞内移行は transport の機構たけで はなく，免度学的機序の関与することる考えられる.

脂質に関して得られた鉿木 ${ }^{39}$ の成績からは，炎症症状 を伴う場合の花胞内容液に triglycerid が著しい上昇を 
示している，咅胞内 triglycerid の明来に咸しては，食

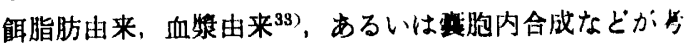
えられるが，椠胞内容夜を，脂筫を含まないRinger 水 と交換しても，24時間後には内容液中に脂筫成分が帢出

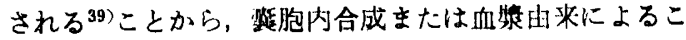
とが考え易い. Triglycerid は，エネルギー代賭の通か ら脂質の inactive form と考えられ ${ }^{32)}$ これが esterase あるいは lipaseにより加水分解されて glycerol と迶離 脂肪酸に分かれて初めて active form になるといら ${ }^{32)}$. また，生体の過剩のエネルギ一は，主として triglycerid （1 部は glycogen）として踷えられるか，渴上皮絒胞に おいては，食触由来の triglycerid が進倠脂肪酸と $\beta$ monoglycerid に分解され，膜を透過して絊胞内に入り， 脂肪酸とともに triglycerid に再合成されるといわれ $ろ^{33)}$.

したがって，感染集胞の堨合にその内容液中の triglycerid 值が上䒜を示すことは，壁上皮の修復機転に伴

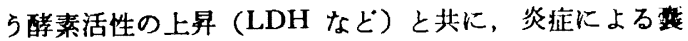
胞の activeな metabolism に対し，そのエネルギー供 給に関連して triglycerid か加水分解され active form に移行して行き，一方では補給のための triglycerid が 血漿由来あるいは籍胞内合成によって内容液中にその量 が增するのと考えられる.

一方，襄胞内 cholesterol の由来については，これま でに多くの記載がみられるが21,34 37)，その折出の機序に 関してはいまた明らかではないよらである。一般に血中 の cholesterol は，全て遊離型に水解されて細胞に吸収 されるが，衰胞内においてもやはり遊離型 cholesterol が多いといわれる27) しかし惑胞内 cholesterol は遊離 型で取り込まれるとしても, lipoprotein, triglyceridなら び phospholipid と何らかの関俰を持ちながら平衡を 保っているものと思われる。 また，前述した如く，亚胞 壁に物質輸送の機構があるとすれば，その機能を考える 上で蛋白と脂質の関係が，たとえば hydrophobic bond ${ }^{30}$ となり輸送物質（電解質イオンなど）の carrier として の役割を担っているのかも知れないしかしこの点に関 しては今後の検討を待たねばならない。

以上の成績から，顎骨要胞の内容夜を楧成する諸成分 は，単なる浸透圧や半透膜のような性質たけで成り立っ ているものとは考えがたく, 震胞壁の免疫学的機構7,31), 重胞上皮の分泌機能 ${ }^{13,14)}$, 炎症細胞の液化機転 ${ }^{1,18 \sim 20)}$, なとに加えて慗胞壁上皮層には能動輸送の機構が関与し て内容液か眝溜し，一定の平衡が保たれるものと考えら れる.さらに，整胞が感染した場合にはこの平衡関係が

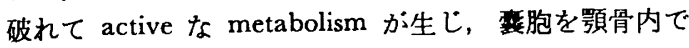
増大させることになるものと考えられる，なお，エナメ ル上皮尰の場合は，腫痬自体の増殖に依存した増大様式 をとるものと思われる。

\section{V. 結镉}

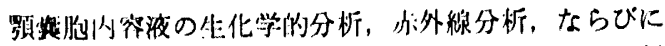

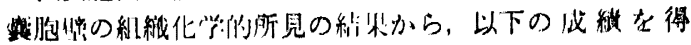
た.

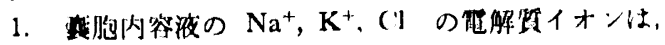

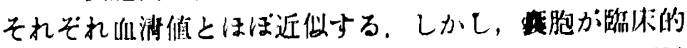

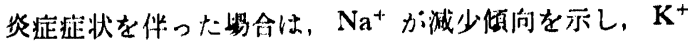

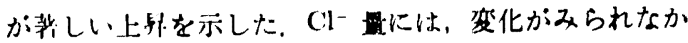
った

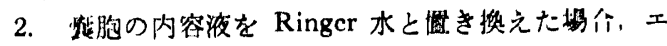

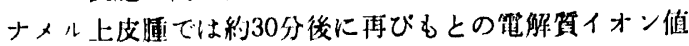
を示した，これに刘し，その他の顎骨竞胞では90分以上 を要した。

3. 内容液中の alkaline-phosphatase 活性値は，血清 の場合とほほ類似するが，歎胞が感染するとその活性は 上年を示す。Acid phosphatase 活性は，エナメル上皮 尰の場合を除き，いずれの芸胞においてる著しい上昇を 示した。ささらに $\mathrm{LDH}$ 活性は，一般に血清值よりも著明 に高い値を示し，炎症の有無による差は認めなかった。

4. エナメル上皮腫内容液の蛋白質は，分子量の小さ いものが多く，分子量の大きくなるに従ってその存在量 に減少の傾向がみられた，その他の胞内容夜では，こ のよらな傾向を認めなかった。

5. 高速液体クロマトグラフィーの結果, 变胞内容液 の albumin 含量は，血清における含量とほほ等しい か， $\alpha-, \beta-, \gamma$-globulin の含有量は，それぞれ血清值よ りも多かった.

6. 内容液の cholesterol 量は，血清値にほほ近似す るが，感染表胞の場合，その含有量に低下の傾向が示さ れた。これに対し， $\beta$-lipoprotein と triglycerid の量 は，感染により上昇を示した。

7. Folch 法で抽出した脂質分画について赤外線吸収 スペクトル法による分析の結果，血清中に検出されるも のの全てが,内容液中にも認められた。

8. 变胞壁上皮層には，組織化学的に $\mathrm{SDH}, \mathrm{LDH}$, glucose-6-phosphate dehydrogenase ならびに $\mathrm{Na}^{+}-\mathrm{K}^{+}$ATPase 活性なとの酵素活性の局在することが示され た. とくに SDH 活性は基底細胞層に強く，表層に向 $5 に$ 従い減少し，これに対し glucose-6-phosphate dehydrogenase 活性は表層に強く，基底細胞層に向うに 従い減少を示し，両酵素活性の分布形式は反対の関係を 示した.

以上の成績から，顎襄胞の内容液の由来，ならびにそ の停滞機構に関して，整胞には能動輸送機構が存在す る可能性につき述べた.

本論交の要旨の一部は第20回日本口腔外科学会総 
会（昭和50竹 9 月）に招いて茀爽した。

\section{文胴}

1) Counsell, A. ('.: The pathology of dental cysts, Br 1)enl J, 53: 69, 1932.

2) Harris, M. and Pannel, G.: Fibrinolytic activity in dental cysts, (Mal Surg, 35: 818, 1973.

3) Stokke, T.: ()molic pressure in colontogenic cysts, Acta odont scand, 14: 65, 1956.

4) Toller, P.A.. Experimental investigation into factors concerning the growth of y ysts of the jaws, Proc roy Soc Med, 41: 681, 1948.

5) Toller, P.A.: Permeability of cyst walls in vivo, Investigations with radioactive tracers, Proc roy Soc Med, 59: 724, 1966.

6) Toller, P.A.: Origine and growth of cysts of the jaw, Ann Coll Surg Engl, 40: 306, 1967.

7) Toller, P.A. and Holborow, E.J.: Immunoglobulins and immunoglobulin-containing cells in cysts of the jaws, Lancet, 11: 178, 1969.

8) Toller, P.A.: Protein substances in odontogenic cyst fluids, Br dent J, 128: 317, 1970.

9) Toller, P.A.: The osmolarity of fluids from cysts of the jaws, Br dent J, 129: 275, 1970.

10) Toller, P.A.: Immunological factors in cysts of the jaw, Proc roy Soc Med, 64: 555, 1971.

11) Frithiof, L. and Hägglund, G.: Ultrastructure of the capsular epithelium of radicular cysts, Acta odont scand, 24: 23, 1966.

12) James, W.W.: Do epithelial odontomes increased in size by their own tension? Proc roy Soc Med, 19: 73, 1926.

13) Klammt, J. und Stosiek, P.: Untersuchungen über die Ursachen der Vergrösserung entzündlicher Kieferzysten, Duetache Zahn-, Mundund Kieferheilkunde, 61: 1, 1973.

14) Main, D.M.G.: The enlargement of epithelial jaw cysts, Odont Rev, 21: 29, 1970.

15) Shear, M.: The histogenesis of the dental cysts, Dent Practit dent Rec, 13: 238, 1963.

16) Stokke, T.: osmotic pressure in odontogenic cysts, Acta odont scand, 14: 65, 1956.

17) Tratman, E.K.: Diffusion as a factor in the increase in size of dental and dentigerous cysts, Br dent J, 66: 515, 1939.

18) Hill, T.J.: The epithelium in dental granuloma, J dent Res, 10: 323, 1930.

19) James, W.W. and Counsell, A.: A histological study of the epithelium associated with chronic apical infection of the teeyh, $\mathrm{Br}$ dent $\mathrm{J}, 53$ : 463, 1932.

20) Tschistowitsch, T. und Mechteis, J.: Über dir Rolle des Epillucls inden W'urzelgranulomen, \% Stomat, 28: 1163, 1930.

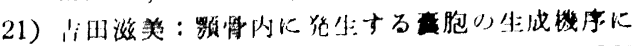

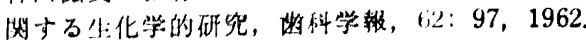

2:2) liold l, J. cl al.: Preparation of lipide extracts from brain lissue, J Biol (liem, 191: 833, 1951.

2.3) Nachlas, M.M. it al.: (ylexhemiral drmonstration of surcinic deliydrogenase by the use

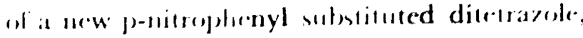
J llivi ( ylo, 5: 420, 1957.

24) Batkat, T. and Andersom, P.J.: Histere hemistry, Tlieory, praclice, and bibliography, Jin.ber Med l)iv Harper \& Row Ine, New York, 1963, p 313.

25) War hstein, M. and Mr.ivl. E.: Histochemistry of hepatic phosphatases at a physiologic $\mathrm{pH}$ with special referencr to the demonstration of bile canaliculi, Am J clin Path, 27: 13, 1957.

26) Ten ('atc, A.R.. The epithelial cell rests of Malassez and the genesis of the dental cyst, Oral Surg, 34: 956, 1972.

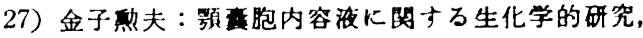
口科誌, 18: 2, 1972.

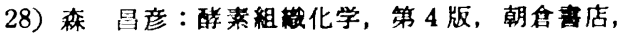
東京, 1969, P 125.

29）中尾真：Na，K-ATPase，蛋白效核醉萦, 20: 130,1975 .

30) 中尾 真：生体膜の生化学（小田玩三，佐藤了, 中尾真編)，朝会書店，東京，1969，p 140.

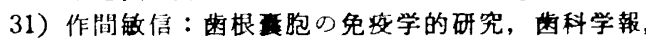
$74: 312,1974$.

32）内藤周幸：脂質の代謝と役割，医学のあゆみ， 78: 254, 1971 .

33）内藤周幸：脂肪吸収におけ子和胞内過程，医学 のあゆみ, 94: 414, 1975.

34) Thoma, K.H. and Goldman, H. M.: Oral pathology, ed 5, Mosby Co, St Louis, 1960, p 418.

35) Shear, M.: Cholesterol in dental cysts, Oral Surg, 16: 1465, 1963.

36) Foldes, F.F. and Murphy, A.J.: Distribution of cholesterol, cholesterol esters and phospholipid phosphorus in normal blood, Proc Soc Exp Biol Med, 62: 215, 1946.

37) 石川梧郎, 秋吉正豊 : 口腔病理学第 2 巻, 第 2 版, 永末書店, 京都, 1971, p 388-390.

38）井上章, 品川嘉也：能動渝送，第 1 版，南江 堂, 東京, 1969, p 5 .

39）鉿木 貢：顎，口腔疾患の臨床的考察，第 5 報, 䪽骨鸾胞の臨床生化学的考察（続）一特に術後 性頓部凖胞内容液の脂質移行について一, 日口 科誌, 25：211， 1976. 